\title{
Manajemen Pendistribusian Zakat Produktif Pada Badan Amil Zakat Nasional (BAZNAS) Kota Padang Panjang
}

\section{Management Of Produktive Zakat Distribution At The National Amil Zakat Agency (BAZNAS) Padang Panjang City}

\author{
Amri Effendi, Widi Nopiardo, Rizal Fahlefi, Fitri Dayana \\ Jurusan Manajemen Zakat dan Wakaf, Fakultas Ekonomi dan Bisnis Islam \\ Institut Agama Islam Negeri Batusangkar \\ amri.effendi.ma@gmail.com,widinopiardo@iainbatusangkar.ac.id, \\ rizalfahlefi@iainbatusangkar.ac.id, fitridayana1997@gmail.com,
}

Manuscript received 01 November 2021, processed 06 November 2021, published 31 Desember 2021

Abstract. Useful zakat is a zakat circulation model which can make mustahiq produce something persistently, with rakat resources that have been gotten. This review means to recognize and portray the dispersion of useful rakat conveyed by BAZNAS Padang Panjang City to the local area to increment mustahiq pay and to distinguish and depict the deterrents looked by BAZNAS Padang Panjang City in appropriating the useful zakat. The sort of exploration that scientists use is field examination or field research. The exploration strategy utilized is illustrative subjective technique. The circulation of useful zakat completed by BAZNAS Padang Panjang City depends on the Padang Panjang Makmur Program where the general execution has been working out positively. Be that as it may, $B A Z N A S$ Padang Panjang City is as yet encountering issues in the conveyance, remembering the absence of HR for overseeing mustabiq who get useful rakat, overall the mustabiq zakat in Padang Panjang City has gotten useful zakat, so from the SOP side of BAZNAS they deferred the dispersion due to mustabiq zakat. can just get qakat 1 (once) in 3 years except if their business encounters a catastrophe

Keywords: Management, distribution, Produktive, Zakat.

Abstrak: Zakat produktif adalah model pendistribusian zakat yang dimana dapat membuat para mustahiq menghasilkan sesuatu secara terus menerus, dengan harta zakat yang telah diterima. Penelitian ini bertujuan untuk mengetahui dan mendiskripsikan pendistribusian zakat produktif yang didistribusikan oleh BAZNAS Kota Padang Panjang kepada masyarakat untuk meningkatkan pendapatan mustabiq dan untuk mengetahui dan mendiskripsikan kendala-kendala yang dihadapi oleh pihak BAZNAS Kota Padang Panjang dalam mendistribusikan zakat produktif tersebut. Jenis penelitian yang peneliti gunakan adalah penelitian lapangan atau field research. Dengan metode penelitian yang digunakan adalah metode kualitatif deskriptif. Pendistribusian zakat produktif yang dilakukan oleh BAZNAS Kota Padang Panjang berdasarkan pada Program Padang Panjang Makmur dimana pelaksanaannya secara keseluruhan sudah berjalan dengan dengan baik. Namun BAZNAS Kota Padang Panjang masih mengalami kendala dalam pendistribusian antara lain kurangnya tenaga sumber daya manusia dalam melakukan pengawasan terhadap mustahiq yang menerima zakat produktif, pada umumnya mustahiq zakat Kota Padang Panjang sudah mendapatkan zakat produktif, jadi dari sisi SOP BAZNAS mereka ditunda pendistribusiannya karena mustahiq zakat hanya bisa mendapatkan zakat 1 (satu) kali dalam 3 tahun kecuali usaha mereka mengalami musibah.

Kata Kunci: Manajemen, Pendistribusian, Zakat, Produktif. 


\section{PENDAHULUAN}

Zakat adalah salah satu rukun pokok dan termasuk salah satu rukun islam. Secara bahasa arti kata zakat berasal dari bahasa Arab dari akar kata zakat mengandung beberapa arti seperti membersihkan, bertumbuh dan berkah. Yang sering terjadi dan banyak ditemukan dalam Al-Quran dengan arti membersihkan, yaitu terdapat dalam Al-Quran surat AlBaqarah ayat 43 : (Syarifuddin, 2010:37)

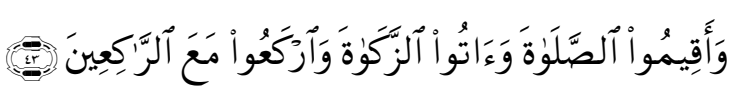

Artinya:"Dan laksanakanlah sholat, tunaikanlah

zakat dan rukuklah bersama orang orang rukuk.". (Al-Baqarab:43)

Al-Qur'an juga menyebutkan pujian bagi orang-orang yang menunaikan kewajiban zakat dengan sungguh-sungguh dan memberikan ancaman bagi siapa saja yang dengan sengaja meninggalkannya. Zakat diambil dari orang-orang yang berkewajiban zakat (muzakki) dan kemudian diberikan kepada orang yang berhak menerima (mustahiq). ( Fahrurrozi, 2017: 5)

Menurut ajaran Islam harta yang dizakati itu akan tumbuh berkembang, bertambah karena suci dan berkah membawa kebaikan dalam hidup dan kehidupan yang punya. Jika dirumuskan, maka zakat adalah bagian dari harta yang wajib diberikan oleh setiap muslim yang memenuhi syarat kepada orang-orang tertentu dengan syarat-syarat tertentu pula. Syarat-syarat tertentu itu ialah nisab, haul, dan kadarnya. (Ali, 2006: 38)

Berdasarkan amanat Undang-Undang nomor 23 Tahun 2011, bahwa dana zakat dapat didistribusikan pada dua jenis kegiatan besar, yakin kegiatan konsumtif dan produktif. Kegiatan konsumtif ádalah kegiatan yang berupa bantuan untuk menyelesaikan masalah yang bersifat mendesak dan langsung habis setelah bantuan tersebut digunakan. Sementara kegiatan produktif ádalah kegiatan yang diperuntukkan bagi usaha produktif yang bersifat jangka menengah-panjang. Dampak dari kegiatan produktif ini, umumnya bisa dirasakan walaupun dana Zakat, Infak Shadaqah atau lebih dikenal dengan (ZIS) yang diberikan sudah habis terpakai. Lebih jauh, pemberdayaan dana Zakat, Infak Shadaqah (ZIS), seperti makanan, kesehatan dan pendidikan. Apabila kebutuhan tersebut sudah terpenuhi atau terdapat kelebihan, alokasi dapat diperuntukkan bagi kegiatan usaha yang produktif melalui program pemberdayaan yang berkesinambungan. (Sri Fadilah, 2017:157-158)

Demikian zakat produktif adalah pemberian zakat yang dapat membuat para penerimanya menghasilkan sesuatu secara terus-menerus, dengan harta zakat yang telah diterimanya. Zakat produktif dengan demikian adalah zakat dimana harta atau dana zakat yang diberikan kepada para mustahiq tidak dihabiskan akan tetapi dikembangkan dan digunakan untuk membantu usaha mereka, sehingga dengan usaha tersebut mereka dapat memenuhi kebutuhan hidup secara terusmenerus. (Lestari, 2015:25-26)

Salah satu Badan Amil Zakat resmi yang dikelola pemerintah yaitu Badan Amil Zakat Nasional (BAZNAS) Kota Padang Panjang. Badan Amil Zakat Nasional (BAZNAS) Kota Padang Panjang selain sebagai Lembaga Amil Zakat yang berperan dalam meningkatkan kesejahteraan umat melalu pendistribusian zakat kepada mustahik. Salah satu bentuk usaha mengatasi kemiskinan melalui pendistribusian zakat produktif yang merupakan program Padang Panjang Makmur. Penyaluran ini berbentuk bantuan modal (berbentuk barang) untuk berdagang dan peralatan untuk usaha dalam mencari nafkah.

Salah satu upaya yang dilakukan oleh BAZNAS Padang Panjang dalam mencapai tujuan zakat sebagaimana yang termaksud 
dalam Undang-Undang Nomor 23 pasal 3 Tahun 2011tentang Pengelolaan Zakat yang bertujuan meningkatkan efektifitas dan efisiensi pelayanan dalam pengelolaan zakat adalah dalam Program Padang Panjang Makmur.

\section{Tabel 1}

\section{Pendistribusian Zakat Produktif Pada}

Program Padang Panjang Makmur BAZNAS Kota Padang Panjang Tahun 2018-2020

\begin{tabular}{|l|l|l|}
\hline Tahun & $\begin{array}{l}\text { Pendistribus } \\
\text { ain Zakat } \\
\text { Produktif }\end{array}$ & $\begin{array}{l}\text { Pengumpula } \\
\text { n Zakat }\end{array}$ \\
\hline $\mathbf{2 0 1 8}$ & $\begin{array}{l}\text { Rp. } \\
1.310 .625 .000\end{array}$ & $\begin{array}{l}\text { Rp. } \\
3.080 .722 .000\end{array}$ \\
\hline $\mathbf{2 0 1 9}$ & $\begin{array}{l}\text { Rp. } \\
1.066 .565 .000\end{array}$ & $\begin{array}{l}\text { Rp. } \\
3.830 .924 .155\end{array}$ \\
\hline $\mathbf{2 0 2 0}$ & $\begin{array}{l}\text { Rp. } \\
1.099 .030 .000\end{array}$ & $\begin{array}{l}\text { Rp. } \\
4.543 .793 .694\end{array}$ \\
\hline
\end{tabular}

Sumber: Laporan Pendistribusian Zakat BAZNAS Kota Padang Panjang 2018-2020

Dari tabel di atas dapat dijelaskan bahwa pada tahun 2018 dana zakat produktif yang didistribusikan melalui program Padang Panjang Makmur yaitu sebesar Rp. 1.310.625.000, dan pada tahun 2019 sebesar Rp. 1.066.565.000, sedangkan pada tahun 2020 pendistribusian dana zakat untuk program Padang Panjang Makmur adalah Rp. 1.099.030.000. Dengan adanya peningkatan dan penurunan (fluktuatif) terhadap jumlah pendistribusian dana zakat produktif melalui program Padang Panjang Makmur dari tahun 2018 sampai tahun 2020 hal ini akan berkaitan dengan manajemen pendistribusian yang dilakukan oleh pihak BAZNAS Kota Padang Panjang.

\section{METODE PENELITIAN}

Jenis penelitian yang digunakan adalah penelitian lapangan atau field research. Metode penelitian yang digunakan adalah metode deskriptif kualitatif. Dalam penelitian ini pembahasan difokuskan pada manajemen pendistribusian zakat produktif pada Badan Amil Zakat Nasional (BAZNAS) Kota Padang Panjang. Penelitian ini dilakukan di kantor Badan Amil Zakat Nasional (BAZNAS) Kota Padang Panjang Provinsi Sumatera Barat Jln. Mr. Assa'at No 14 Padang Panjang.

Penelitian ini menggunakan dua sumber data, yaitu :

1. Sumber Data Primer

Data primer ini merupakan datayang dikumpulkan oleh peneliti sendiri atau dirinya sendiri. Informasi yang diperoleh langsung dari pelaku yang melihat dan terlibat langsung dalam penelitian yang dilakukan oleh peneliti.

Dalam penelitian ini yang termasuk sebagai sumber data primer adalah data yang diambil dari hasil wawancara dengan Ketua, Wakil III Bidang Perencanaan Keuangan dan pelaporan, Wakil II Bidang pendistribusian dan staf pendistribusian di BAZNAS Kota Padang Panjang.

2. Sumber Data Sekunder

Sumber data sekunder yaitu data yang langsung dikumpulkan oleh peneliti sebagai penunjang dari sumber pertama. (Arikunto, 2002:145)

Data sekunder adalah data yang telah lebih dahulu dikumpulkan dan dilaporkan oleh orang atau instansi di luar dari peneliti sendiri, walaupun yang dikumpulkan itu sesungguhnya adalah data yang asli. Data ini biasanya diperoleh dari perpustakaan atau dari laporan-laporan penelitian terdahulu. Data sebagian diambil dari jurnal dan buku-buku mengenai zakat.

Analisis data dilakukan dalam penelitian ini memiliki 4 tahap yaitu pengumpulan data, reduksi data, penyajian data dan penarikan kesimpulan. 


\section{Pengumpulan data}

Dalam pengumpulan data ada beberapa hal yang perlu lakukan. Seperti obsevasi awal yang dilakukan.

\section{Data Reduction (Reduksi Data)}

Di sini peneliti meringkas kembali catatan lapangan pada saat observasi dan wawancara, pengelompokan data, memilah dan membuang data yang tidak ada kaitannya dengan tema penelitian sehingga data yang diolah itu merupakan data yang tercakup dalam lingkup penelitian.

\section{Data Display (Penyajian Data)}

Langkah ini dilakukan dengan menyajikan sekumpulan informasi yang terkumpul yang memberi kemungkinan adanya penarikan kesimpulan.

\section{Conclusion Drawing/Verification} (Penarikan Kesimpulan atau Verifikasi)

Kesimpulan atau verifikasi adalah tahap akhir dalam proses analisa data. Pada bagian ini peneliti mengutarakan kesimpulan dari data-data yang telah diperoleh. Dalam tahapan ini peneliti menarik kesimpulan berdasarkan pada data yang telah direduksi dan disajikan yang merupakan jawaban dari rumusan masalah yang diangkat dalam penelitian dengan kalimat yang singkat, padat dan mudah dipahami.

\section{HASIL PENELITIAN PEM BAHASAN}

Manajemen dalam bahasa Inggris disebut dengan management diambil dari kata manage yang berarti mengurus, mengatur melaksanakan, mengelola, sedangkan management itu sendiri memiliki dua arti, yaitu Pertama sebagai kata benda yang berarti direksi atau pimpinan. Kedua berarti ketata laksanaan, tata pimpinan, pengelolaan.

$$
\text { Menurut Mary Parker Follet, }
$$
manajemen adalah: seni dalam menyelesaikan pekerjaan melalui orang lain. Hal ini disebabkan karena kepemimpinan memerlukan kharisma, stabilitas emosi, kewibawaan, kejujuran, kemampuan menjalin hubungan antar manusia yang semuanya itu banyak ditentukan oleh bakat seseorang dan sukar dipelajari.

Sedangkan menurut Stoner, manajemen adalah proses perencanaan, pengorganisasian, pengarahan dan pengawasan usaha-usaha para anggota organisasi dan penggunaan sumber daya organisasi lainnya agar mencapai tujuan organisasi yang telah ditetapkan. (Furqon, 2015: 2-3)

Pendistribusian berasal dari kata distribusi yaitu secara bahasa berasal dari bahasa Inggris distribution yang artinya penyaluran dan pembagian, atau pengiriman barang atau jasa kepada beberapa orang atau tempat. Distribusi merupakan alur perpindahan ataupun pertukaran suatu komoditi dari satu pihak ke pihak yang lain dengan atau tanpa konpensasi sebagai alat penukar komoditi. (Mutfi Afif, Sapta Oktiadi, 2018:139-140)

Sistem distribusi zakat mempunyai sasaran dan tujuan. Sasarannya adalah pihakpihak yang diperbolehkan menerima zakat; sedangkan tujuannya adalah sesuatu yang dapat dicapai dari alokasi hasil zakat dalam kerangka sosial ekonomi, yaitu meningkatkan kesejahteraan masyarakat dalam bidang perekonomian sehingga dapat memperkecil kelompok masyarakat miskin, yang pada akhirnya akan meningkatkan kelompok muzakki.

Pola pendistribusian zakat saat ini juga mengalami inovasi, bentuk inovasi distribusi dikategorikan dalam empat bentuk yaitu, Distribusi konsumtif tradisional, konsumtif 
kreatif, produktif tradisional, produktif kreatif. (Rahmah. 2019: 15)

Pendistribusian zakat (masharif al-zakat) adalah pembagian atau pemberian zakat kepada yang berhak menerimanya (almustahaqun laha). Jadi pendistribusian zakat adalah penyaluran zakat kepada orang yang berhak menerima (mustabiq) baik secara konsumtif ataupun produktif. Sistem pendistribusian zakat dari masa ke masa mengalami perubahan. Semula lebih banyak disalurkan untuk kegiatan konsumtif tetapi belakangan ini banyak pemanfaatan dana zakat untuk kegiatan produktif. Upaya seperti ini dapat diharapkan dapat tumbuh strata dari yang terendah (mustahiq) ke yang lebih tinggi (muzakki). (Burhanuddin, 2017:3)

Zakat produktif merupakan model pendistribusian zakat yang dapat membuat para mustabiq menghasilkan sesuatu secara terus menerus, dengan harta zakat yang telah diterima. Zakat produktif adalah harta zakat yang diberikan kepada mustabiq tidak dihabiskan atau dikonsumsi tetapi dikembangkan dan digunakan untuk membantu usaha mereka, sehingga dengan usaha tersebut mustabiq dapat memenuhi kebutuhan hidup secara terus menerus. (Anwar, 2018:45)

Sehingga pengelolaan zakat dapat terwujud sesuai dengan tujuan pasal 3 UndangUndang No. 23 tahun 2011 tentang pengelolaan zakat yaitu:

1. Meningkatkan efektifitas dan efisiensi pelayanan dalampengelolaan zakat;

2. Meningkatkan manfaat zakat untuk mewujudkan kesejahteraan masyarakat dan penanggulangan kemiskinan. (UndangUndang No. 23 Tahun 2011 Tentang Pengelolaan Zakat)

Distribusi zakat dapat dilakukan dengan berbagai cara, tergantung dari kebijakan manajemen Badan atau Lembaga Zakat yang bersangkutan. Adakalanya disalurkan langsung pada mustahik dengan pola konsumtif dan adakalanya diwujudkan dalam bertuk produktif atau dengan cara memberikan modal atau zakat dapat dikembangkan dengan pola investasi. Namun lebih kepada bagaimana cara atau metode menyampaikan dana zakat kepada sasaran dalam pengertian lebih luas, sesuai dengan ruh dan tujuan syariat. Bagaimana cara pemberian yang tepat guna, efektif manfaatnya dengan sistem yang serba guna dan peran serta fungsi sosial ekonomi dari zakat.

\section{Bentuk Pendistribusian Dan Pendayagunaan Zakat}

Pola distribusi dan pendayaguanaan zakat bisa dikategorikan dalam empat bentuk: Pertama, distribusi yang bersifat konsumtif. Kedua, distribusi yang bersifat konsumtif kreatif. Ketiga, distribusi yang bersifat produktif tradisional, keempat, distribusi yang bersifat produktif kreatif. Umumnya pola pendistribusian bisa dikategorikan kedalam empat bentuk yaitu sebagai berikut :

a. Konsumtif Tradisional maksud pendistribusian zakat secara konsumtif tradisional adalah bahwa zakat dibagikan kepada mustahiq dengan secara langsung untuk kebutuhan konsumsi sehari-hari, seperti pembagian zakat fitrah berupa beras dan uang kepada fakir miskin setiap Idul Fitri atau pembagian zakat mal secara langsung oleh para murakki kepada mustabiq yang sangat membutuhkan karena ketiadaan pangan atau karena mengalami musibah. Pola ini merupakan program jangka pendek dalam rangka mengatasi permasalahan umat.

b. Konsumtif Kreatif adalah Pendistribusian zakat yang diwujudkan dalam bentuk barang konsumtif dan 
digunakan untuk membantu orang miskin dalam mengatasi permasalahan sosial dan ekonomi yang dihadapinya. Bantuan tersebut antara lain berupa alat-alat sekolah dan beasiswa untuk para pelajar, bantuan sarana ibadah seperti sarung dan mukena, bantuan alat pertanian, seperti cangkul untuk petani, gerobak jualan untuk pedagang kecil.

c. Produktif

Konvensional

Pendistribusian zakat secara zakat yang diberikan dalam bentuk barang-barang produktif, di mana dengan menggunakan barang-barang tersebut, para muzzaki dapat menciptakan suatu usaha, seperti pemberian bantuan ternak kambing, sapi perahan atau untuk membajak sawah, alat pertukangan, mesin jahit.

d. Produktif Kreatif adalah Pendistribusian zakat yang diwujudkan dalam bentuk pemberian modal bergulir, baik untuk pemodalan proyek sosial, seperti pembangunan sosial, pembangunan sekolah, sarana kesehatan atau tempat ibadah maupun sebagai modal usaha untuk membantu atau bagi pengembangan usaha para pedagang atau pengusaha kecil. (Fitri, 2017:162)

Adapun pendayagunaan zakat telah dijelaskan dalam Undang-Undang No. 23 tahun 2011 sebagai berikut:

a. Zakat dapat didayagunakan untuk usaha produktif dalam rangka penanganan fakir miskin dan peningkatan kualitas umat.

b. Pendayagunaan zakat untuk usaha produktif sebagaimana dimksud pada ayat (1) dilakukan apabila kebutuhan dasar mustahik telah terpenuhi. (Undang-undang No.23 Tahun 2011 Tentang Pengelolaan Zakat)
Pendistribusian zakat secara produktif, yaitu dana zakat yang disalurkan khusus bagi mustahik yang dianggap produktif. Maksudnya dana zakat ini diberikan dengan tujuan memberdayakan mustahik supaya lebih produktif. Sehingga ke depannya mustabiq ini dapat berkembang dan mandiri. Dalam hal ini mustahik diberikan modal untuk pengembangan usaha. Disini BAZNAS bertugas untuk mendampingi, memberi pengarahan serta mengawasi mustahik untuk mengetahui sejauh mana mustahik yang diberi kepercayaan tersebut mengalami kemajuan. (Mahzumi, 2019: 69).

\section{Perencanaan Pendistribusian Zakat Produktif}

Dalam melakukan pendistribusian zakat produktif BAZNAS Kota Padang Panjang memiliki 5 program kerja yaitu program Padang Panjang Makmur, Padang Panjang Cerdas, Padang Panjang Peduli, Padang Panjang Sehat, Padang Panjang Dakwah. Pada program Padang Panjang Makmur yang mana pada program ini menyangkut penyaluran zakat produktif untuk modal usaha bagi masyarakat yang tidak mampu. BAZNAS mendata, memverifikasi, menentukan dan menetapkan berapa orang yang mesti dibantu, jenis bantuan apa yang akan diberikan kemudian berapa indeknya.

Sebelum melakukan pendistribusian zakat produktif BAZNAS Kota Padang Panjang melakukan beberapa perencanaan seperti :

a. Merencanakan rapat pendistribusian zakat produktif

Perencanaan ini berguna untuk membahas tentang realisasi pendistribusian dana zakat produktif (modal usaha). Dalam rapat yang 
dilakukan oleh BAZNAS dibagi dua yaitu:

1) Rapat Internal

Rapat ini dilakukan oleh pengurus BAZNAS Kota Padang Panjang yaitu ketua, wakil ketua serta pelaksanan.

2) Rapat Eksternal

Rapat ini dengan jajaran Pimpinan organisasi perangkat daerah (OPD) Kota Padang Panjang yang ada di Kota Padang Panjang dan dinas terkait dalam pendistribusian zakat produktif.

b. Merencanakan sosialisasi kepada masyarakat

Pers dan media cetak elektronik merupakan media yang sangat ampuh dalam merubah prilaku khususnya dalam menumbuhkan kepercayaan masyarakat terhadap keberadaan Badan Amil Zakat Nasional Kota Padang Panjang. Dalam meningkatkan kepercayaan masyarakat terhadap BAZNAS Kota Padang Panjang dalam mengelola zakat. Oleh karena itu pimpinan selalu memanfaatkan seluruh media yang ada untuk mempulikasikan segala bentuk kegiatan pengelolaan zakat. Baik publikasi zakat tentang pengumpulan pendistribusian serta kegiatan-kegiatan ceremonial lainya.

BAZNAS juga bekerja sama dengan instansi terkait seperti Kominfo dan Radio yang ada di Kota Padang Panjang untuk mensosialisasikan program yang ada di BAZNAS Kota Padang Panjang sehingga seluruh unsur masyarakat mengetahui program yang ada di BAZNAS termasuk zakat produktif atau bantuan modal usaha pada Program Padang Panjang Makmur.

c. Kuota jumlah penerimaan mustabiq
Dalam penentuan kuota penerima (mustabiq) pada Program Padang Panjang Makmur ini BAZNAS Kota Padang Panjang tidak membatasi. Artinya tidak ada batasan-batasan berapa jumlah orang yang akan menerima zakat produktif ini.

d. Merencanakan sumber data calon mustahiq

Untuk

perencanaan

mendapatkan data calon mustabiq BAZNAS Kota Padang Panjang dimana BAZNAS mendapatkan data langsung dari mustahik yang mengajukan proposal ke kantor BAZNAS dan juga melalui usulan dari pihak kelurahan yang mengirimkan data ke BAZNAS dan melakukan kordinasi dengan dinas KOPERINDAG.

e. Merencanakan alokasi dana zakat produktif

Dalam menetapkan alokasi dana untuk 5 program BAZNAS itu diputuskan dalam rapat pimpinan, dan hasil rapat pimpinan tersebut dituangkan dalam bentuk RAKT dan Standar Operasional Prosedur (SOP)

f. Merencanakan kriteria mustabiq dan persyaratan administrasi yang harus dipenuhi

dalam perencanaan kriteria dan Kategori mustabik tetap mengarah pada surat At-Taubah ayat 60 mengenai Asnaf 8 dan juga berdasarkan SOP BAZNAS Kota Padang Panjang.

Pada program Padang Panjang makmur ini BAZNAS telah menetapkan kriteria bagi mustabiq yang telah ditetapkan dalam Standar Operasional Prosedur (SOP). Adapun kriteria umum calon mustabik untuk penerima zakat sebagai berikut: 
1) Muslim yang taat kepada Allah SWT

2) telah menjadi warga Kota Padang Panjang minimal 2 (orang) tahun, yang dibuktikan dengan KTP/ KK

3) Keluarga yang berpenghasilan $\mathrm{Rp}$ 450.000/ bulan per jiwa Diprioritaskan yang terdaftar kedalam kelompok Basis Data terpadu (BDT)

4) Nilai kontrak rumah maksimal $\mathrm{Rp}$ 7.500.000,-

5) Diutamakan yang belum menerima zakat 3 (tiga) tahun terakhir dari tahun berjalan untuk Program Padang Panjang Makmur

6) Bagi mustahiq yang tidak bertempat tinggal sesuai dengan KTP, tapi masih dalam wilayah Kota Padang Panjang, maka mustahiq tersebut bisa meminta surat keterangan berdomisili di tempat yang baru dari Pemerintah setempat. Sebaliknya jika mustahiq tersebut berdomisili di luar Kota Padang Panjang tidak bisa dilayani dengan dana zakat

Adapun kriteria khusus calon mustabik untuk penerima zakat produktif pada Program Padang Panjang Makmur sebagai berikut:

1) Tidak sedang menerima bantuan sejenis dari pihak lain

2) Punya minat/ bakat usaha serta memiliki tempat usaha

3) Berprilaku baik dengan warga lingkungan

4) Tidak dalam keadaan meminjam dengan bank dan rentenir

Seorang mustabiq yang memiliki kriteria seperti tersebut diatas, dapat mengajukan permohonan modal usaha atau diusulkan oleh pihak kelurahan atau pihak lain kepada pimpinan Badan Amil Zakat Nasional Kota Padang
Panjang dengan melampirkan persyaratan administrasi diantaranya Fotocopy KTP dan KK yang berdomisili di Kota Padang Panjang, Surat keterangan miskin dari kelurahan, Surat keterangan berusaha dari Pemerintah setempat dengan mencantumkan jenis usahanya dan Calon penerima harus mengikuti pembinaan dari BAZNAS

g. Merencanakan survei mustahik zakat produktif

Dalam survei mustahik ini akan dilakukan oleh tim survei. Dengan rencana akan melakukan observasi terhadap mustabiq secara langsung ke tempat mustabik yang akan dibantu untuk modal usaha. Serta melakukan wawancara dengan calon mustahiq guna untuk mengetahui lebih dalam kehidupan sehari-hari calon mustahiq, jumlah pendapatan calon mustabik, untuk mengetahui bagaimana bentuk dan perkembangan usaha mustahik yang akan dibantu.

h. Merencanakan bentuk dan pola pendistribusian zakat produktif

Dalam pendistribusian zakat produktif pada Program Padang Panjang Makmur BAZNAS memakai sistem barang. BAZNAS tidak memberikan bantuan tunai kepada mustabiq. Ini berguna untuk menghindari penyalah gunaaan zakat produktif oleh mustahiq. BAZNAS memberikan rekomendasi terhadap yang bersangkutan untuk belanja keperluan di tempat yang mereka pilih.

Sebelum pendistribusikan zakat produktif dilakukan BAZNAS sudah merencanakan untuk memberikan pembinaan kepada mustabiq meliputi keagamaan, kewirausahaan dan manajemen keuangan terlebih dahulu. 
Agar zakat yang didistribusikan lebih cepat berkembang sehingga dapat meningkatkan pendapatan perekonomian mustahiq serta taraf hidupnya.

Berbeda dengan halnya zakat produktif untuk sektor pertanian khusus untuk sektor pertanian BAZNAS melakukan pendistribusian dalam bentuk uang tunai kepada mustabik karena adanya keterbatasan akan pengadaan bahan dan untuk pertanian.

i. Merencanakan pengawasan terhadap mustahiq zakat produktif

Dalam pengawasan ini, BAZNAS Kota Padang Panjang merencanakan pengawasan terhadap mustabiq zakat yang menerima zakat produktif dilakukan secara berkala yaitu 1 (satu) kali dalam sebulan yang dilakukan oleh tim pembinan dari BAZNAS Kota Padang Panjang. Guna untuk melihat perkembangan usaha yang dijalankan oleh mustahik. Diharapkan dari pengawasan ini dapat meningkatkan usaha serta melihat keseriusan mustahik dalam mengembangkan usahanya, dan juga untuk pengambilan keputusan selanjutnya terhadap apa yang telah direncanakan.

\section{Pengorganisasian}

Dalam pengelolaan zakat, setelah melakukan perencanaan, pengorganisasian merupakan unsur yang sangat diperlukan. Hal ini terkait dengan koordinasi pemanfaatan sumberdaya manusia dan sumberdaya zakat yang telah dikumpulkan oleh lembaga zakat. Pengorganiasian dalam pengelolaan zakat bertujuan, agar zakat dapat dikelola dengan kredibel dan efektif serta tepat sasaran untuk mencapai tujuan. Pengorganisasian yang baik adalah dilakukan oleh sumberdaya manusia yang mempunyai kapasitas dalam mengorganisasi dengan efektif dan efesien. (Atabik, 2015: 58)

Dalam pendistribusian zakat produktif BAZNAS Kota Padang Panjang membentuk pengelompokan dalam pendistribusian dalam beberapa bagian seperti satu orang bertugas sebagai front office bagian ini bertugas untuk melayani mustabik dan muzzaki yang datang. Selanjutnya dua orang di tugaskan bagian survey, satu orang untuk wilayah Padang Panjang Timur dan satu orang lagi di wilayah Padang Panjang Barat. Satu orang bagian keuangan. Satu bagian pelaporan dan SIMBAZNAS.

\section{Pelaksanaan Pendistribusian Zakat Produktif}

Pendistribusian merupakan kegiatan menyalurkan sejumlah harta dari zakat yang sudah terhimpun oleh BAZNAS Kota Padang panjang untuk diberikan kepada mustabiq zakat. Dalam hal ini zakat disalurkan pada Program Padang Panjang Makmur melalui zakat produktif (modal usaha).

Dalam pelaksanaan pendistribusian zakat produktif meliputi waktu dan tempat penyerahan serta bagaimana prosedur penyerahannya. Setelah ditetapkannya mustahiq penerima zakat produktif pada program Padang Panjang Makmur maka BAZNAS akan melakukan penyerahan zakat kepada mustahiq dari BAZNAS Kota Padang Panjang ke masing-masing kelurahan yang ada di Kota Padang Panjang.

Pada program Padang Panjang Makmur BAZNAS Kota Padang Panjang yang dilakukan pada tahap pelaksanaan dan model seleksi ini tidak jauh berbeda 
dengan program lainnya. Untuk dapat mendapatkan zakat produktif di BAZNAS Kota Padang Panjang, calon mustabiq harus melewati tahapan seleksi yang telah diberikan oleh pihak BAZNAS Kota Padang Panjang. Adapun model tahapan seleksi yang dimaksud seperti berikut:

a. Mustabiq atau pihak kelurahan mengantarkan berkas permohonan ke Kantor BAZNAS Kota Padang Panjang dengan menemui petugas front office dengan ucapan salam.

b. Petugas front office melayani dengan menjawab salam dengan sopan, santun dan senyum sambil menanyakan maksud dan tujuan kedatangannya

c. Petugas front office melakukan pemeriksaan atas permohonan yang diserahkan oleh mustahiq. Jika persyaratan permohonan belum lengkap, maka petugas mengembalikan permohonan tersebut untuk dilengkapi. Jika kelengkapan administrasi telah lengkap maka petugas akan memberikan bukti penerimaan permohonan kepada mustabiq tersebut.

d. Petugas front office mencatat data calon mustahiq tersebut ke dalam buku agenda harian serta mencatatkan pula ke dalam aplikasi BAZNAS Kota Padang Panjang

e. Petugas front office meneruskan berkas permohonan tersebut ke tim survey lapangan untuk menelusuri ke sahihan data dan kondisi terkini mustahiq.

f. Tim survey lapangan, melaporkan hasil penelusuran seorang calon mustahiq ke Kepala Pelaksana, bahwa calon mustabiq tersebut berhak menerima dana zakat dengan perkiraan besaran dana yang akan diberikan atau tidak berhak menerima

g. Kapala pelaksana melakukan pengolahan lebih dalam tentang hasil survey calon mustabiq dengan menetapkan kelayakan dan besaran zakat yang akan diberikan kepada mustahiq tersebut. Atau menetapkan ketidaklayakan seorang calon mustabiq

h. Kepala pelaksana meneruskan hasil survey seorang calon mustabiq tentang diterima atau tidak diterimanya proposal yang bersangkutan kepada wakil ketua bidang pendistribusian untuk disahkan dalam rapat pleno pimpinan BAZNAS Kota Padang Panjang

i. Hasil kesepakatan pleno pimpinan dilanjutkan lagi dalam rapat tim koordinasi penanggulangan kemiskinan (TKPK) Kota Padang Panjang. Hal ini dilakukan untuk menghindari terjadinya salah dan ganda sasaran

j. Selanjutnya finaslisasi calon mustabiq penerima dana zakat program Padang Panjang Makmur akan di koordinasikan dengan pihak kelurahan

k. Hasil koordinasi dengan pihak kelurahan akan dilanjutkan dengan pembuatan Surat keputusan pimpinan dan surat permintaan pencairan dana zakat, diteruskan kepada wakil ketua bidang keuangan dan pelaporan untuk diambilkan dana zakat ke bank pengumpul untuk di salurkan ke mustabiq

1. Wakil ketua bidang keuangan dan pelaporan menyerahkan dana zakat Program Padang Panjang Makmur kepada wakil ketua bidang pendistribusian untuk disalurkan kepada mustabiq dalam suatu acara 
resmi dengan urutan acara sebagai berikut :

1) Pembinaan mustabiq tentang pengelolaan usaha dan manajemen keuangan serta pembinaan mental

2) Laporan ketua BAZNAS Kota Padang Panjang

3) Pengarahan Walikota Padang Panjang

4) Mustabiq menandatangani tanda terima

m. Pimpinan BAZNAS dan Amil Zakat Kota Padang Panjang akan melakukan pengawasan dan monitoring serta pembinaan kepada mustabiq yang telah menerima dana zakat Program Padang Panjang Makmur 1 (satu) x sebulan. Hasil pengawasan, monitoring dan pembinaan harus dilaporkan kepada wakil ketua bidang pendistribusian dan pendayagunaan melalui kepala pelaksana untuk di evaluasi.

\section{Pengawasan Program Padang Panjang Makmur}

Pengawasan merupakan point yang sangat penting dalam menjalankan perencanaan guna untuk melihat apakah kegiatan yang sudah direncana dapat berjalan dengan baik dan untuk pengambilan keputusan apakah sudah sesuai dengan rencana yang telah ditetapkan diawal. Apabila pengawasan tidak dilakukan ini dapat mengakibatkan rencana tidak berjalan sesuai apa yang telah ditetapkan dan jauh dari apa yang diharapkan. Untuk Pengawasan bedasarkan SOP BAZNAS Kota Padang Panjang, pimpinan BAZNAS dan Amil Zakat Kota Padang Panjang akan melakukan pengawasan dan monitoring serta pembinaan kepada mustabiq yang telah menerima dana zakat Program Padang Panjang Makmur 1 (satu) x sebulan. Hasil pengawasan, monitoring dan pembinaan harus dilaporkan kepada wakil ketua bidang pendistribusian dan pendayagunaan melalui kepala pelaksana untuk di evaluasi.

Dalam melakukan pengawasan BAZNAS melakukan kerja sama dengan pihak terkait seperti Dinas Pertanian, Dinas Sosial dan Koperindag agar lebih mudah dalam melakukan pengawasan terhadap mustahik zakat yang meneriman zakat produktif pada Program Padang Panjang Makmur. Pengawasan yang dilakukan oleh tim BAZNAS Kota Padang Panjang itu sendiri kepada para mustabiq zakat yang menerima zakat produktif pada Program Padang Panjang Makmur itu belum maksimal dilakukan karena lebih kepada mustabik yang akan mendapatkan zakat produktif.

6. Kendala-Kendala dalam Pendistribusian Zakat Produktif di BAZNAS Kota Padang Panjang

Pendistribusian zakat produktif di kalangan umat Islam, menoreh pengaruh besar terhadap perwajahan realitas perekonomian dan sosial pada masyarakat kita. Dibuktikan dengan betapa besarnya manfaat dari alokasi zakat yang disalurkan secara produktif dibanding konsumtif. Di antara manfaat yang sangat menonjol adalah menjadi solusi untuk mengurangi kemiskinan dan membina kemandirian mustabiq, walaupun masih dalam skala kecil, disebabkan dana zakat belum bisa dimobilisasi secara optimal. (Zalikha Siti, 2016: 13-14)

Dalam pendistribusian zakat produktif oleh BAZNAS Kota Padang Panjang ini mengalami beberapa kendala, kendala tersebut dibagi menjadi 2 diantaranya ialah sebagai berikut : 
1. Internal

a. Kurangnya SDM dalam melakukan survey terhadap mustabik yang sudah menerima zakat produktif.

b. Kuranganya pengawasan yang dilakukan oleh BAZNAS Kota Padang Panjang terhadap mustahiq yang menerima zakat produktif.

\section{Ekternal}

Adapun kendala dalam pendistribusian zakat produktif dari luar adalah sebagai berikut :

a. Data mustabiq yang dikirimkan oleh pihak kelurahan untuk rekomendasi mustabik mendapatkan zakat ekonomi produktif ini pada umumnya sudah pernah mendapatkan.

\section{KESIMPULAN}

Dari hasil penelitian yang telah peneliti lakukan di BAZNAS Kota Padang Panjangtentang "Pendistribusian Zakat Produktif Dalam Upaya Peningkatan Perekonomian Pendapatan Mustahik Oleh Badan Amil Zakat Nasional (BAZNAS) Kota Padang Panjang" maka daapat dikemukakan kesimpulan bahwa :

1. Pelaksanaan pendistribusian zakat produktif yang terjadi di BAZNAS Kota Padang Panjang secara keseluruhan sudah berjalan dengan baik. Adapun yang melatar belakangi adanya praktek tersebut dikarenakan BAZNAS Kota Padang Panjang menggunakan sistem pembagian zakat produktif berbentuk barang, jadi tidak adanya terjadi penyalahgunaan zakat produktif oleh mustabik. Dengan harapan dengan adanya program ini masyarakat lebih mandiri serta meningkatkan perekonomian masyarakat. Zakat produktif di BAZNAS Kota Padang Panjang ini yang di distribusikan sekali dalam 3 bulan ini diharapkan mustabiq mengalami peningkatan dalam pendapatan di bidang usaha mereka. Hal ini menunjukan bahwa zakat produktif mempunyai peran yang cukup besar dalam peningkatan usaha mustabiq. Adapun yang menikmati zakat produktif adalah pedagang-pedagang P\&D, Tailor, bengkel, salon, laundry, reparasi kursi tamu dan spring bed, pencucian karpet dan lainnya.

2. Faktor penghambat atau kendala dalam pendistribusian zakat produktif di BAZNAS Kota Padang Panjang terdapat beberapa hambatan yang dihadapi antara lain: (a) kurangnya tenaga Sumber daya manusia dalam melakukan pengawasan terhadap mustabik zakat yang sudah menerima zakat produktif (b) dalam melakukan pengawasan terhadap mustabiq zakat yang menerima zakat produktif BAZNAS melakukan kerja sama dengan instansi terkait seperti : Dinas Pertanian, Dinas Sosial dan KOPERINDAG. Namun pengawasan yang dilakukan oleh BAZNAS masih belum maksimal. Sehingga dengan kurangnya pengawasan dari BAZNAS Kota Padang Panjang terhadap mustabiq akan memperlambat pencapaian target dari pendistribusian zakat produktif itu sendiri. (c) data mustabik yang dikirimkan oleh pihak kelurahan untuk rekomendasi mendapatkan zakat produktif ini sudah pernah mendapatkan zakat produktif.

\section{DAFTAR KEPUSTAKAAN}

Ali, Muhammad. D. (2006). Sistem Ekonomi Islam Zakat dan Wakaf. Jakarta: Universitas Indonesia (UI-Press).

Anwar, A. T. (2018). Zakat Produktif Untuk Pemberdayaan Ekonomi Umat. Jurnal Zakat dan Wakaf ZISWAF, Vol. 5, No. 1, Juni 2018. 
Arikunto, S. (2002). Prosedur Penelitian Suatu Pendekatan Praktek. Jakarta: Rieneka Cipta.

Atabik, A. (2015). Manajemen Pengelolaan Zakat Yang Efektif Di Era Kontemporer Jurnal Zakat dan Wakaf ZISWAF, Vol. 2, No. 1, Juni 2015

Burhanuddin. (2017). Pendistribusian Zakat Melalui Perspektif Figh dan PerundangUndangan di Indonesia. Malang: UIN Maulana Malik Ibrahim.

Fahrurrozi, A. (2017) Pemberdayaan Ekonomi Masyarakat Melalui Pendistribusian Zakat Produktif Dari BAZNAS Kota Yogyakarta. Yogyakarta : Universitas Alma Ata

Fitri, M. (2017). Pengelolaan Zakat Produktif sebagai Instrumen Peningkatan Kesejabteraan Umat. Economica: Jurnal Ekonomi Islam-Volume 8, Nomor 1 (2017) : 149-173 ISSN: 2085-9325 (print); 2541-4666 (online) DOI: http://dx.doi.org/10.21580/economi ca.2017.8.1.1830.

Furqon, A (2015). Manajemen Zakat. Semarang: BPI Ngaliyan

Lestari, S. (2015). Analisis Pengelolaan Zakat Produktif Untuk Pemberdayaan Ekonomi. Semarang: Universitas Silam Negeri Walisongo.

Mahzumi, A. Abid, (2019) Peran Zakat Produktif Dalam Upaya Peningkatan Pendapatan Mustabik (Study Kasus Di $B A Z N A S$ Kota Semarang), Semarang: Universitas Islam Negeri Walisongo

Mutfi Afif, S. O. (2018). Efektifitas Distibusi Dana Zakat Produktif dan Kekuatan Serta Kelemahannya Pada BASNAZ Magelang. Islamic Economics Journal

Rahmah, S. (2019). Manajemen Pendistribusian Zakat Di Badan Amil Zakat Nasional (Baznas) Provinsi Kalimantan Selatan Alhaddarah: Jurnal Ilmu Dakwah, 2019 Vol. 18, No. 1
Syarifuddin, A. (2010). Garis-Garis Besar Fiqih edisi 1 cetakan 3. Jakarta: Kencana.

Sri Fadilah, R. L. (2017). Organisasi Pengeleloan Zakat (OPZ) Pengelola Zakat dari Aspek Zakat. Kajian Akuntansi Vol. 18 No.2 September 2017 ISSN :1693-0164

SOP baznas koTA PADANG PANJANG 2020

Undang-Undang No. 23 Tabun 2011 Tentang Pengelolaan Zakat.

Wawancara dengan amil Syamsuarni, S.Ag, ketua BAZNAS Kota Padang Panjang pada tanggal 2 Juni 2021

Wawancara dengan amil Syaiful Ardi,Lc bidang pendistribusian dan pendayagunaan BAZNAS Kota Padang Panjang Pada tanggal 4 Agustus 2021

Wawancara dengan amil Drs.H. Mastoti bidang keuangan dan pelaporan BAZNAS Kota Padang Panjang pada tanggal

Zalikha, S. 2016. Pendistribusian Zakat Produktif Dalam Perspektif Islam. Jurnal Ilmiah Islam Futura, Vol. 15. No. 2 Februari 2016. 